\title{
Preliminary Genotoxicity Assessment of Cadmium, Lead, and Mercury on Different Planktonic Organisms
}

\author{
José Silvestre Delgadillo-Díaz de León', Gustavo Emilio Santos-Medrano', \\ Roberto Rico-Martínez ${ }^{1}$, Isidoro Rubio-Franchini², Daniel Robles-Vargas ${ }^{1 *}$ \\ ${ }^{1}$ Centro de Ciencias Básicas, Departamento de Química. Benemérita Universidad Autónoma de Aguascalientes. \\ Av. Universidad 940, C.P. 20131, Aguascalientes, Ags. México \\ ${ }^{2}$ Instituto de Salud del Estado de Aguascalientes. Laboratorio Estatal de Salud Pública, Av. Siglo XXI 105, \\ Morelos, Desarrollo Especial Centro de Morelos, C.P. 20270. Aguascalientes, Ags. México
}

Received: 13 February 2021

Accepted: 8 May 2021

\begin{abstract}
Plankton is important for water reservoirs as they are essential for web chains and control populations of bacteria and organic particulates by their filter-feeding behavior. Generally, toxicity tests evaluate mortality or reproduction, however, comet assay has emerged as a useful tool to assess adverse effects on aquatic organisms such as genotoxicity. The present study aimed to value the genotoxic effect of three heavy metals on three zooplanktonic species. Comet assay conditions were adapted in order to obtain minimum DNA migration in negative control and maximum sensitivity in treatments with cadmium, hydrogen peroxide, lead, and mercury. DNA damage was evaluated using two different methods based on the percentage of DNA in the tail. According to our results, mercuryinduced the greatest DNA damage on the three test organisms while cadmium and lead exhibited low genotoxicity. Euchlanis dilatata showed the highest sensitivity to mercury followed by the ciliate and the cladoceran. The comet assay is a liable and consistent technique for DNA damage screening in planktonic organisms. To date, this is the first report for genotoxicity assessment using metals on a rotifer, which represents a reference for evaluating genotoxicity on planktonic species poorly studied.
\end{abstract}

Keywords: comet assay, ecotoxicology, freshwater organisms, metals, relative sensitivity

\section{Introduction}

Water pollution is mainly originated by deposition of agricultural, domestic and industrial, wastes. Among

*e-mail: danrvargas@gmail.com

xenobiotics commonly found in aquatic ecosystems, heavy metals such as cadmium, lead and mercury are of great concern due their persistence and toxicity [1-3]. These metals tend to bioconcentrate and may break down DNA molecules and modify location of nitrogen bases that eventually could lead to a mutation or chromosome rearrangement as a result of cellular metabolism [4-8]. 
Planktonic organisms are important components of aquatic ecosystems as they perform key roles in trophic chains and have been widely used in bioassays due to: a) vast diversity, b) short life cycle, c) high reproduction rate, and d) high sensitivity to environment disturbance $[9,10]$.

In ecotoxicology, the cladoceran Daphnia magna is a well-known reference organism for aquatic biomonitoring because of its sensitivity to chemicals. It has been used to assess the toxicity of several kinds of chemicals, including hydrocarbons, metals, pesticides, and pharmaceuticals; the end-points more assess are: mortality, reproduction, and feeding behavior and enzymatic tests as well. Also, D. magna has been used to stablish regulations by important environmental agencies like the Environmental Protection Agency of the United States (EPA) and the Organization for Economic Cooperation and Development (OECD) [1114].

Recently, DNA-damage quantification in aquatic organisms has been considered a useful biomarker to evaluate the genotoxic potential of toxicants. In 1999, the Comet assay, initially used to detect DNAdamage in individual cells has been adjusted to be implemented in genotoxicity testing [15]. To date, research about the genotoxicity of metals has been focused mainly in molluscs (bivalves and gastropods), annelids (polychaetes and oligochaetes) and insects. Besides, there are just a few reports for the protozoan Tetrahymena thermophila, and the crustacean Daphnia magna [16].

For genetic damage assessment, Comet Assay is outstanding due to its high sensitivity toward low levels of DNA damage and fast performance. Furthermore, its analysis is based on a single cell and can be applied to any eukaryotic cell population $[17,18]$. This study aimed to assess the possible genotoxic effect of cadmium, lead, and mercury on Daphnia magna, Euchlanis dilatata, and Paramecium caudatum comparing the relative sensitivity of the cladoceran against the rotifer and protozoan.

\section{Material and Methods}

\section{Culture Conditions}

The rotifer Euchlanis dilatata and the cladoceran Daphnia magna were cultured at 25 and $20^{\circ} \mathrm{C}$, respectively, in a bioclimatic chamber with 16:8 (light: darkness) photoperiod. The EPA culture media was used for both organisms which were prepared with $96 \mathrm{mg} \mathrm{NaHCO}, 60 \mathrm{mg} \mathrm{CaSO} \cdot 2 \mathrm{H}_{2} \mathrm{O}, 60 \mathrm{mg} \mathrm{MgSO}_{4}$ and $4 \mathrm{mg} \mathrm{KCl}$ per liter of deionized water. This is a synthetic moderately hard water medium $(80-100 \mathrm{mg} / \mathrm{L}$ as $\mathrm{CaCO}_{3}$ ) with a $7.5 \mathrm{pH}$ [19]. E. dilatata was fed with Nannochloropsis oculata (strain LB2164 of UTEX, Culture Collection of Algae at the University of Texas of Austin) while the cladoceran was maintained with
Raphidocelis subcapitata (strain 1648 of UTEX, Culture Collection of Algae at the University of Texas of Austin). The ciliate Paramecium caudatum was cultured in wheat infusion media $(2.5 \mathrm{~g} / \mathrm{L})$ using the same culture conditions of light and temperature as with the rotifer.

\section{Toxicity Tests with Hydrogen Peroxide}

Briefly, 10 neonate females less than 24-h-old hatched from amictic eggs of Euchlanis dilatata and ten protozoans were placed in each well of 24-well polystyrene plates (Costar Co., USA) with a final volume of $1 \mathrm{~mL}$. For the cladoceran, 10 neonate females less than 24-h-old were placed in glass flasks with a final volume of $100 \mathrm{~mL}$. Tests were performed without feeding or renewal the EPA medium. Tests conditions were: for $E$. dilatata and $P$. caudatum, $25^{\circ} \mathrm{C}$ and $20^{\circ} \mathrm{C}$ for D. magna. All tests were conducted with a photoperiod 16:8 h (light:darknes) and lasted 24-h. Three replicates of five concentrations of $\mathrm{H}_{2} \mathrm{O}_{2}$ (J.T. Baker, 30-32\%) were used depending on the species including a negative control (EPA medium). At the end of the test (24h), death organisms were counted.

\section{Intoxication Treatment}

Cadmium $(\mathrm{Cd})$ and lead $(\mathrm{Pb})$, both dissolved in nitric acid at $2 \%$, and mercury $(\mathrm{Hg})$ as chloride in powder (all from Sigma-Aldrich Co.) were used to perform toxicity assays in disposable and sterile Petri dishes. Experimental conditions were $24 \mathrm{~h}$ exposure, photoperiod $16: 8$ at $20^{\circ} \mathrm{C}$ for D. magna and $25^{\circ} \mathrm{C}$ for $E$. dilatata and P. caudatum. Assay begins placing adult females of cladocerans and rotifers in glass flasks without food. Protozoans were centrifugated at $8000 \mathrm{rpm}$ during 10 minutes and washed three times with EPA medium to eliminate excess food, then, organisms were counted in a Neubauer chamber $\left(\right.$ Brand $\left.^{\mathrm{TM}}\right)$. After $24 \mathrm{~h}, 30$ cladocerans, 100 rotifers (neonates $<24 \mathrm{~h}$ for both species) and 300 protozoans were used to perform the tests. Dilutions were made with EPA medium to reach a final nominal concentration of $100 \mu \mathrm{g} / \mathrm{L}$ of $\mathrm{Cd}$ and $\mathrm{Pb}$, and $5 \mu \mathrm{g} / \mathrm{L}$ of $\mathrm{Hg}$. These concentrations are below their respective hazard concentration for $50 \%$ of species $\left(\mathrm{HC}_{50}\right)$ [20]. Thus, the $\mathrm{HC}_{50}$ values for invertebrates are: 268 for $\mathrm{Cd}, 3002$ for lead and, $64.5 \mu \mathrm{g} / \mathrm{L}$ for mercury [20]. Positive control with hydrogen peroxide corresponds to the NOEC for each species, thus, a concentration of 3,10 , and $30 \mu \mathrm{M}$ was used for E. dilatata, D. magna, and P. caudatum, respectively. Also, negative control with EPA medium was included in all treatments.

\section{Determination of Actual Metal Concentrations}

Actual exposure concentrations of metals were determined through atomic absorption spectrophotometry (Perkin-Elmer AAnalyst 100), 
following the recommended analytical method [21]: graphite furnace for cadmium (3030E) and lead (3113B) and mercury by hydride generator (3112B). $\mathrm{N}=3$.

\section{Comet Assay}

Comet Assay was performed as described in [22, 23] with modifications, which consist in: 1) two-layers were applied instead of three-layers of agarose (the top layer of regular melting point agarose was omitted) $[22], 2)$ in the lysis treatment, slides were stored at $4^{\circ} \mathrm{C}$ for 24 hours in substitution of 4 weeks [23], and 3) electrophoresis was run at $25 \mathrm{~V}$ for 30 min rather than $15 \mathrm{~V}$ for $25 \mathrm{~min}[22,23]$.

\section{Isolation of Cells and Preparation of Single-Cell Suspensions}

After exposure to metals, living organisms were processed by the alkaline comet assay to obtain a single cell suspension for each test organism. For E. dilatata (100 rotifers) and D. magna (30 cladocerans), organisms were crushed with a plastic tipped sprayer during one minute. The experiments on paramecia were performed with whole organisms (300 ciliates). Then, the cell suspension was centrifuged at $10,000 \mathrm{rpm}$ for $5 \mathrm{~min}$. An Eppendorf tube was used to mix $100 \mu \mathrm{L}$ of the precipitate obtained with $200 \mu \mathrm{L}$ of Low Melting Agarose (LMA) at $0.8 \%$ (Sigma), this preparation was kept at $37^{\circ} \mathrm{C}$ within a water bath and used to prepare slides.

\section{Slides Preparation}

Slides were cleaned with the $99 \%$ ethanol, rinsed with sterile distilled water and dried in the oven at $40^{\circ} \mathrm{C}$. For each slide the first layer of regular melting point agarose at $0.8 \%$ (Sigma) was applied, then, a second layer containing cell suspension and LMA $(100 \mu \mathrm{L})$ was added. Immediately, slides were covered with a coverslip ( $24 \times 50 \mathrm{~mm}$ ) and allowed to harden on a battery of ice for one minute. Then, slides were incubated at $4^{\circ} \mathrm{C}$ for $2 \mathrm{~min}$ and coverslips were discharged.

\section{Cell Lysis}

The lysis was carried out by immersing slides in a lysis chamber which contains: the buffer solution $1 \%$ Triton X-100 (J.T. Baker), 2.5 M NaCl (J.T. Baker), 100 mM Na $\mathrm{EDTA}_{2}$ (J.T. Baker), $10 \mathrm{mM}$ Tris (Hycel), pH 10. The lysis chamber was stored at $4^{\circ} \mathrm{C}$ overnight to obtain the nuclei.

\section{Denaturation and Electrophoresis}

After lysis, slides were placed in a horizontal electrophoresis chamber (BioRad) containing an electrophoresis alkaline buffer $(\mathrm{pH}>13)$ with: $1 \mathrm{mM}$
EDTA (J.T. Baker), $300 \mathrm{mM} \mathrm{NaOH}$ (J.T. Baker), for $30 \mathrm{~min}$. Then, electrophoresis was started at a voltage of $25 \mathrm{~V}$ and $300 \mathrm{~mA}$ and allowed to run for $30 \mathrm{~min}$.

\section{Neutralization}

Once the electrophoresis was finished, slides were washed with a neutralization buffer $(0.4 \mathrm{M}$ Tris- $\mathrm{HCl}$ solution at $\mathrm{pH} 7.5$ ) at $4^{\circ} \mathrm{C}$ for 5 minutes in a plastic tray. After neutralization, slides were dehydrated with $99 \%$ ethanol for one minute and then were stored in dark to avoid direct light at room temperature.

\section{Image Analysis and Quantification of DNA Damage}

Slides were placed in a plastic tray with ethidium bromide $20 \mu \mathrm{L} / \mathrm{mL}$ (Sigma) in agitation for one minute to allow nuclei staining. Visualization was performed using a Leica DMLS fluorescence microscope (40X). Two replicates of 100 nuclei per slide were counted in dark conditions to avoid DNA damage. Image analysis was carried out with the plug-in OpenComet $1.3 .1 \mathrm{v}$ (2016) of the ImageJ software $1.47 \mathrm{~V}$ [24] to assess the \% DNA in the tail which was classified into 5 categories (0-4) according to Berchieri-Ronchi et al. [25].

DNA damage was calculated with the categories and $\%$ DNA in the tail using the following formula:

$$
\begin{gathered}
{[(2.5 \times \text { cells } 0+12.5 \times \text { cells } 1+30 \times \text { cells } 2} \\
+60 \times \text { cells } 3+90 \times \text { cells } 4)] \sum \text { cells }(1)[25]
\end{gathered}
$$

...where: category (\% DNA in the tail), $0(<5), 1(5-20)$, 2 (20-40), 3 (40-80) and 4 (>80).

\section{Relative Sensitivity}

Relative sensitivity was calculated using the formula stated below [26]:

$$
\begin{gathered}
\mathrm{RS}=\log (\text { mean } \% \text { DNA in the tail } \\
\text { D. magna } / \text { mean \%DNA in the tail } i)
\end{gathered}
$$

...where: $\mathrm{RS}=$ relative sensitivity; mean $D$. magna $=$ mean $\%$ DNA in the tail value for $D$. magna and $=$ mean $\%$ DNA in the tail value for species $i$. A value of zero indicates a sensitivity equal to that of D. magna, positive value $D$. magna is less sensitive, negative value D. magna is most sensitive.

\section{Statistical Analysis}

The media lethal concentration (LC50) was obtained with a linear regression using the logarithm of the concentration and the probit value of the mortality percentage. The concentration where no effect is observed (NOEC), was calculated with an ANOVA and the Tukey Honestly-Significant-Difference (HSD) to determine the statistical difference between means of control and test concentrations. The \% DNA in 
the tail results were analyzed with a one-way analysis of variance test (ANOVA) with a comparison of the means using the Tukey's HSD test. Results were obtained following two different methods that consider \% DNA in the tail: a) by determining the mean and standard error of the total cells in each treatment, and b) by clustering cells according to the extent of damage, thus, mean and standard deviation were estimated to measure DNA integrity. All statistical analysis were performed with Statistica 12 [27].

\section{Results and Discussion}

In the present work, the comet assay was carried out successfully on D. magna, E. dilatata and $P$. caudatum, which has demonstrated to be sensitive to $\mathrm{Cd}, \mathrm{Pb}$, and $\mathrm{Hg}$. We used the percentage of DNA in the tail as characteristic parameter of DNA damage in the tested organisms. Actual concentration of metals during tests were determined by atomic absorption with the following retention percentages: $91.5 \pm 5.43 \%$ $(91.5 \mu \mathrm{g} / \mathrm{L}), \quad 90.41 \pm 1.9 \% \quad(91.4 \mu \mathrm{g} / \mathrm{L}), \quad 81.3 \pm 0.64 \%$ $(4.06 \mu \mathrm{g} / \mathrm{L})$, (mean \pm one $\mathrm{SD}, \mathrm{n}=3$ ) for $\mathrm{Cd}, \mathrm{Pb}$, and $\mathrm{Hg}$, respectively. The actual concentrations indicate the amount of metal that are dissolved in the EPA medium. The median lethal concentrations for the $\mathrm{H}_{2} \mathrm{O}_{2}$ were 5.62, 17.37 and $45.7 \mu \mathrm{M}$ for E. dilatata, D. magna and $P$. caudatum, respectively.

Genotoxic effects of $\mathrm{Cd}, \mathrm{Hg}$, and $\mathrm{Pb}$ have already been reported using in vitro assays; unfortunately, little is known about their effects on planktonic species. To our knowledge, this is the first report about the genotoxicity induced by metals for a rotifer species.

There were no statistical differences $(p<0.05)$ in baseline DNA damage (negative control) between the three species (Fig. 1). Several authors have reported values for negative control ranged from 7.16 to $10.20 \%$ of DNA in the tail for D. magna [28-30], 1.72 to $9.08 \%$ for Ceriodaphnia dubia [28, 30] and 0.32 for Moina macrocopa [31]. In this work, the value for negative control $(8.26 \%)$ is inside the range given previously for $D$. magna (Fig. 1). In the case of $P$. caudatum a value of $6.35 \%$ (Figure 1) of DNA in the tail was determined, this percentage is among the values reported by Dou et al. [32] and Rajapakse et al. [33] (1.61 and $9.22 \%$, respectively) both for the ciliate Tetrahymena thermophila. To date, there are no genotoxicity records for rotifers, however, the \% DNA in the tail in control for E. dilatata was 5.31, thus, this organism has a lower value compared to the protozoan and the cladoceran (Fig. 1).

When comparing positive control (hydrogen peroxide at $10 \mu \mathrm{M})$, our result with D. magna $(30.28 \%$, Fig. 1) is similar to the values reported for the same species by Parella et al. [28] and Lavorgna et al. [30], who recorded 36 and $41 \%$, respectively, although is higher to the percentage (15) found by Pellegri et al. [29]. We assume these differences might be originated by the diet and culture conditions. On the other hand, $P$. caudatum exhibited $30.47 \%$, nevertheless, it was exposed to $30 \mu \mathrm{M}$ while $E$. dilatata was more sensitive since a lower concentration $(3 \mu \mathrm{M})$ induce a higher $\%$ DNA in the tail (86.52). As it was expected, hydrogen peroxide (used as a positive control to monitor DNA damage on cells that underwent metal exposure) induced DNA migration which differs depending on the test organism (Fig. 1). This chemical is one of the most potent agents that cause a significant DNA damage [29].

Fig. 1 shows the genotoxicity considering the percentage of DNA located in the comet's tail, where a higher damage for mercury was observed compared to the negative control $(p<0.05)$ for the three tested species. Therefore, the lowest percentage was recorded in treatments with $\mathrm{Cd}$ and $\mathrm{Pb}$ (ranged from 10.22 to $14.44 \%$ ) for three test organisms while $\mathrm{Hg}$ exhibited the greatest damage especially in E. dilatata $(82.07 \%)$. Daphnia magna showed the lowest damage when it was exposed to $\mathrm{Hg}$, we suggest this response is due to the difference in size compared to $E$. dilatata and $P$. caudatum.

According to our results, the order of genotoxicity induced by metals on the freshwater invertebrates was as follows: mercury $>$ cadmium $=$ lead. Furthermore, data obtained showed the greatest DNA damage when organisms were exposed to mercury at $4.06 \mu \mathrm{g} / \mathrm{L}$ (Fig. 1). It is important to point out that in the case of rotifers and cladocerans, since whole organisms were used, different cell lines were included and represent a possible variation source of DNA damage and differences in their sensitivity to heavy metals.

In relation to treatments with $\mathrm{Cd}$ and $\mathrm{Pb}$, there were no statistical differences between the three organisms, this suggests a similar response for D. magna, $E$. dilatata and P. caudatum. Besides, mercury showed a wide range of damage in the DNA of 38.06-82.07\% for the three tested organisms (Fig. 1), which implies that different mechanisms of repair and detoxification might be occurring depending on the species.

Pelligri et al. [29] determined a $14 \%$ DNA in the tail when D. magna was exposed to $20 \mu \mathrm{g} / \mathrm{L}$ of $\mathrm{Cd}$, although they used neonates less than 24 hours old and extracted the hemolymph for the comet assay. In our study, at $91.5 \mu \mathrm{g} / \mathrm{L}$ of $\mathrm{Cd}$, we recorded a $14.44 \%$ using whole daphnids. On the other hand, Phromchaloem et al. [31] performed the comet assay with M. macrocopa neonates after 48-hour exposure at $160 \mu \mathrm{g} / \mathrm{L}$ of $\mathrm{Cd}$ fed with yeast once a day and obtained $4.44 \%$ DNA in the tail. When comparing our results for D. magna treated with Cd to those obtained by Pelligri et al. [29] and Phromchaloem et al. [31], it is evident that using neonates and a single cell line in the comet assay turned out in an increase on the sensitivity. On the other hand, allowing the organism to eat before the comet assay decreased the sensitivity of the organism.

Di Donato et al. [34] conducted comet assays testing two cell lines (hemocytes and spermatozoa) of 


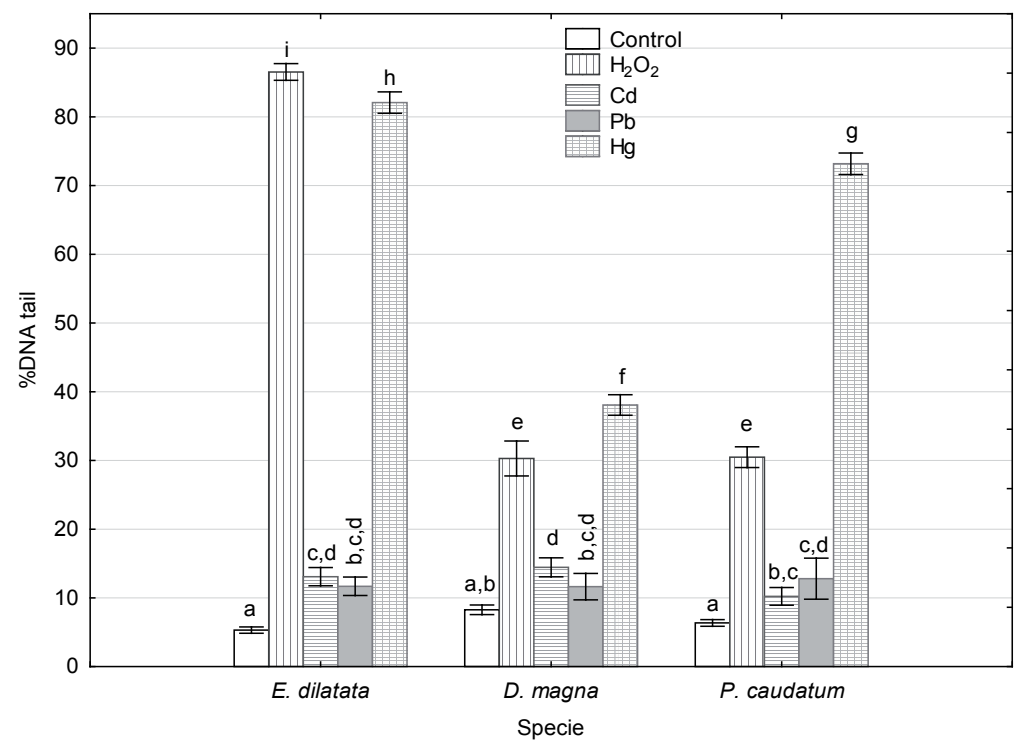

Fig. 1. \% DNA in the tail was determined by the comet assay in the different zooplanktonic species exposed to selected metals $(\mathrm{Cd}=91.5 \mu \mathrm{g} / \mathrm{L}, \mathrm{Pb}=91.4 \mu \mathrm{g} / \mathrm{L}, \mathrm{Hg}=4.06 \mu \mathrm{g} / \mathrm{L})$ and hydrogen peroxide (positive control, E. dilatata $3 \mu \mathrm{M}, D$. magna $10 \mu \mathrm{M}$ and $P$. caudatum $30 \mu \mathrm{M})$. Negative control: EPA medium. Same letters indicate no statistical difference $(\mathrm{p}<0.05) . \mathrm{n}=100$. Bars correspond to mean \pm one SD.

Gammarus elvirae exposed to lead and mercury noted a higher sensitivity to mercury, which is in accordance with our findings for the three studied species.

As indicated in the methodology, a second method to estimate DNA damage was performed by clustering cells in five categories according to the \% DNA in the tail. Table 1 shows the results of DNA damage where four groups can be observed: 1) low damage level for negative controls, cadmium, and lead in the three species studied; 2) medium level of damage for

Table 1. Level of damage to DNA after $24 \mathrm{~h}$ exposure to EPA medium (baseline), hydrogen peroxide (positive control) and selected metals and relative sensitivity of D. magna compared to $E$. dilatata and P. caudatum were calculated. Abbreviations: Dm $=D$. magna, $\mathrm{Ed}=$ E. dilatata, $\mathrm{Pc}=$ P.caudatum,$c f=$ compared to.

\begin{tabular}{|c|c|c|c|c|c|}
\hline \multirow{2}{*}{ Specie } & \multirow{2}{*}{ Treatment } & \multirow{2}{*}{$\begin{array}{c}\text { Category } \\
\text { (Zhao et al.) }\end{array}$} & \multirow{2}{*}{ Grade of damage } & \multicolumn{2}{|c|}{ Relative sensitivity } \\
\hline & & & & $\operatorname{Dm} c f \mathrm{Ed}$ & $\mathrm{Dm} c f \mathrm{Pc}$ \\
\hline E. dilatata & EPA & 1 & Low & - & - \\
\hline P. caudatum & EPA & 1 & Low & - & - \\
\hline D. magna & EPA & 1 & Low & - & - \\
\hline D. magna & $\mathrm{Pb}$ & 1 & Low & - & - \\
\hline P. caudatum & $\mathrm{Cd}$ & 1 & Low & - & 1.11 \\
\hline E. dilatata & $\mathrm{Pb}$ & 1 & Low & 0.98 & - \\
\hline P. caudatum & $\mathrm{Pb}$ & 1 & Low & - & 0.92 \\
\hline E. dilatata & $\mathrm{Cd}$ & 1 & Low & 1.03 & - \\
\hline D. magna & $\mathrm{Cd}$ & 1 & Low & - & - \\
\hline P. caudatum & $\mathrm{H}_{2} \mathrm{O}_{2}$ & 2 & Medium & - & - \\
\hline D. magna & $\mathrm{H}_{2} \mathrm{O}_{2}$ & 2 & Medium & - & - \\
\hline D. magna & $\mathrm{Hg}$ & 3 & High & - & - \\
\hline P. caudatum & $\mathrm{Hg}$ & 3 & High & - & 0.90 \\
\hline E. dilatata & $\mathrm{Hg}$ & 3 & High & 0.87 & - \\
\hline E. dilatata & $\mathrm{H}_{2} \mathrm{O}_{2}$ & 4 & High & - & - \\
\hline
\end{tabular}


D. magna and P. caudatum exposed to hydrogen peroxide; 3) high damage level induced by mercury for the three species and, 4) extremely high by hydrogen peroxide on E. dilatata.

Different attempts to find a more sensitive water quality indicator have been made. As reported by other authors, the comet assay has proven to be reliable to detect damage induced by metals at molecular level [16] and is acquiring relevance in biomonitoring. Pellegri et al. [35] adapted this test using the reference organism $D$. magna to evaluate genotoxicity of water samples collected in several watercourses of a pilot basin located at the Parma district in Italy. Despite the cladoceran is the reference organism proposed by national and international environmental agencies, D. magna might not be that sensitive to metals when compared to other species. Cui et al. [36] found that D. galeata was more sensitive to $\mathrm{Pb}$ than $D$. magna after conducting acute toxicity tests. In terms of relative sensitivity in our study, D. magna showed less sensitivity than $E$. dilatata and P. caudatum for the three heavy metals tested (Table 1). According to Santos-Medrano and Rico-Martínez [26], Simocephalus vetulus and D. pulex exhibited a higher relative sensitivity than $D$. magna to $\mathrm{Cd}$ and $\mathrm{Hg}$, however, D. magna was more sensitive to $\mathrm{Pb}$.

Several studies state that $\mathrm{Cd}, \mathrm{Pb}$, and $\mathrm{Hg}$ cause DNA damage through different mechanisms. Some authors have suggested $[37,38]$ that DNA can offer abundant binding sites for $\mathrm{Cd}$ (mainly $\mathrm{N} 7$ centers in adenine and guanine) which cause breaks and other related DNA damage. Besides, oxidative stress, ions of $\mathrm{Hg}$ also might bind to DNA and produce strand breaks and DNADNA crosslinks, as well as inhibition of DNA repair $[39,40]$. In relation to lead, a revision made by GarcíaLestón et al. [41] includes evidence of genotoxicity induced possibly through inhibition of DNA repair or free radical production.

\section{Conclusions}

The actual work shows significant DNA damage on three zooplanktonic species identifying the rotifer Euchlanis dilatata as the most sensitive species compared to the cladoceran and the protozoan. To the best of our knowledge, this is the first report for genotoxicity assessment using a rotifer. Genotoxic damage was evident for the selected test organisms after exposure to heavy metal concentrations below their HC50 values where the rotifer turned out to be the most sensitive species to $\mathrm{Hg}$, followed by the protozoan and the cladoceran. Genotoxic effects induced by $\mathrm{Cd}$ and $\mathrm{Pb}$ on aquatic invertebrates may be reflected on a population decrease while $\mathrm{Hg}$ could lead to a severe impact at the cellular level as does not allow DNA repair. According to our results and other reports, comet assay is a viable and consistent technique for DNA damage screening in planktonic organisms.

\section{Acknowledgements}

We thank the Benemérita Universidad Autónoma de Aguascalientes (UAA) for the support provided to perform this work.

\section{Conflict of Interest}

The authors declare no conflict of interest.

\section{References}

1. PETERS K., BUNDSCHUH M., SCHÄFER R.B. Review on the effects of toxicants on freshwater ecosystem functions. Environmental Pollution, 180, 324, 2013.

2. NOORHOSSEINI S.A., ALLAHYARI M.S., DAMALAS C.A., MOGHADDAM S.S. Public environmental awareness of water pollution from urban growth: The case of Zarjub and Goharrud rivers in Rasht, Iran. Science of the Total Environment, 599-600, 2019, 2017.

3. GONZÁLEZ-ACEVEDO Z.I., GARCÍA-ZARATE M.A., NÚÑEZ-ZARCO E.A., ANDA-MARTÍN B.I. Heavy Metal sources and anthropogenic enrichment in the environment around the Cerro Prieto Geothermal Field, Mexico. Geothermics, 72, 170, 2018.

4. BEJAOUI S., TELAHIGUE K., CHETOUI I., TRABELSI W., RABEH I., NECHI S., CHALBI E., CHALGAF M., CAFSI M.E.L., SOUDANI N. Effects of lead exposure on redox status, DNA and histological structures in Venus verrucosa gills and digestive gland. Chemistry and Ecology, 36 (5), 434, 2020.

5. ALI H., KHAN E. Bioaccumulation of non-essential hazardous heavy metals and metalloids in freshwater fish. Risk to human health. Environmental Chemistry Letters, 16, 903, 2018

6. VÁZQUEZ-BOUCARD C., ANGUIANO-VEGA G., MERCIER L., ROJAS DEL CASTILLO E. Pesticide residues, heavy metals, and DNA damage in sentinel oysters Crassostrea gigas from Sinaloa and Sonora, Mexico. Journal of Toxicology and Environmental Health, Part A, 77 (4), 169, 2014.

7. BHUYAN M.S., BAKAR M.A., AKHTAR A., HOSSAIN M.B., ALI M.M., ISLAM M.S. Heavy metal contamination in surface water and sediment of the Meghna River, Bangladesh. Environmental Nanotechnology, Monitoring and Management, 8, 273, 2017.

8. RADOMISKY A., LEI K., GIUBILATO E., CRITTO A., LIN C., MARCOMINI A. Bioaccumulation of trace metals in aquatic food web. A case study, Liaodong Bay, NE China. Marine Pollution Bulletin, 137, 555, 2018.

9. RICO-MARTÍNEZ R., ARZATE-CÁRDENAS M.A., ALVARADO-FLORES J., PÉREZ-LEGASPI I.A., SANTOS-MEDRANO G.E. Rotifers as Models for Ecotoxicology and Genotoxicology. In: Ecotoxicology and Genotoxicology: Non-traditional Aquatic Models, Larramendy, M.L., Ed., Royal Society of Chemistry, United Kingdom, 48, 2017.

10. WON EJ., HAN J., KIM DH., DAHMS HU., LEE J.S. Rotifers in Ecotoxicology. In: Rotifers, Hagiwara A., Yoshinaga T., Eds., Fisheries Science Series. Springer, Singapore, 149, 2017. 
11. ZHANG X., XIA X., DONG J., BAO Y., LI H. Enhancement of toxic effects of phenanthrene to Daphnia magna due to the presence of suspended sediment. Chemosphere, 104, 162, 2014.

12. LE QA.V., SEKHON S. S., LEE L., HO KO J., MIN J. Daphnia in water quality biomonitoring - "omic" approaches. Toxicology and Environmental Health Sciences, 8, 1, 2016.

13. SALESA B., FERRANDO M.D., VILLAROEL M.J., SANCHO E. Effect of the lipid regulator Gemfibrozil in the Cladocera Daphnia magna at different temperatures. Journal of Environmental Science and Health, Part A, 0, $1,2016$.

14. TOUMI H., BEJAOUI M., TOUAYLIA S., BURGAPEREZ K.F., FERARD J.F. Effect of carbaryl (carbamate insecticide) on acetylcholinesterase activity of two strains of Daphnia magna (Crustacea, Cladocera). Journal of Environmental Science and Health, Part B, 0, 1, 2016.

15. GLEI M., SCHNEIDER T., SCHLÖRMANN W. Comet assay: an essential tool in toxicology research. Archives of Toxicology, 90, 2315, 2016.

16. GAJSKI G., ZEGURA B., LADEIRA C., POURRUT B., DEL BO C., NOVAK M., SRAMKOVA M., MILIC M., GUTZKOW K. B., COSTA S., DUSISNKA M., BRUNBORG G., COLLINS A. The comet assay in animal models: From bugs to whales - (Part 1 Invertebrates). Mutation Rsearch-Reviews in Mutation Research, 779, 82, 2019.

17. AZQUETA A., COLLINS A.R. The essential comet assay: a comprehensive guide to measuring DNA damage and repair. Archives of Toxicology, 87 (6), 949, 2013.

18. CORTÉS-GUTIÉRREZ E.I., DÁVILA-RODRÍGUEZ M.I., FERNÁNDEZ J.L., LÓPEZ-FERNÁNDEZ C., GOSÁlBEZ A., GOSÁLVEZ J. New application of the Comet Assay: Chromosome-Comet Assay. Journal of Histochemistry \& Cytochemistry, 59 (7), 655, 2011.

19. USEPA. (United States Environmental Protection Agency). Methods for measuring the acute toxicity of effluents and receiving waters to freshwater and marine organisms, EPA-821-R-02-012. Washington. USA. 2002.

20. LIU Z., YAN Z., WANG X., WU J., ZHENG X. Study of Species Sensitivity Distribution for Pollutants. In: Toxic Pollutants in China: Study of Water Quality Criteria, Yan, Z., Liu, Z, Eds., Springer Briefs in Environmental Science, Dordrecht, pp. 69, 2015.

21. APHA. Standard Methods for the Examination of Water and Wastewater. 23 ${ }^{\text {rd }}$. ed.; American Public Health Association/ American Water Works Association/Water Environment Federation, Washington DC. USA, 1545, 2017.

22. SINGH N.P., McCOY M.T., TICE R.R., SCHNEIDER E.L. A simple technique for quantification of low levels of DNA damage in individual cells. Experimental Cell Research, 175, 184, 1988.

23. SAHLMANN A., WOLF R., HOLTH T.F., TITELMAN J., HYLLAND K. Baseline and oxidative DNA damage in marine invertebrates. Journal of Toxicology and Environmental Health, Part A, 80 (16-18), 807, 2017.

24. RASBAND W.S. ImageJ. U. S. National Institutes of Health, Bethesda, Maryland, USA, https://imagej.nih.gov/ ij/, 1997-2018 IMAGEJ.

25. BERCHIERI-RONCHI C.B., KIM S.W., ZHAO Y., CORREA C.R., YEUM K.J., FERREIRA A.L.A., Oxidative stress status of high prolife sows during pregnancy and lactation. Animal, 5, 1774, 2011.

26. SANTOS-MEDRANO G.E., RICO-MARTÍNEZ R. Acute sensitivity comparison among Daphnia magna Straus,
1820 Daphnia Pulex Leydig, 1860 and Simocephalus vetulus Müller, 1776, exposed to nine toxicants. Turkish Journal of Fisheries and Aquatic Scienes, 19 (7), 615, 2018.

27. StatSoft, Inc. (2014). STATISTICA (data analysis software system), version 12. www.statsoft.com.

28. PARRELLA A., LAVORGNA M., CRISCUOLO E., RUSSO C., ISIDORI M. Eco-genotoxicity of six anticancer drugs using comet assay in daphnids. Journal of Hazardous Materials, 286, 5732015.

29. PELlEGRI V., GORBI G., BUSCHINI A. Comet Assay on Daphnia magna in eco-genotoxicity testing. Aquatic Toxicology, 155, 261, 2014.

30. LAVORGNA M., RUSSO C., D’ABROSCA B., PARRELLA A., ISIDORI M. Toxicity and genotoxicity of the quaternary ammonium compound benzalkonium chloride (BAC) using Daphnia magna and Ceriodaphnia dubia as model systems. Environmental Pollution, 210, 34, 2016.

31. PHROMCHALOEM C., NAKPHLAIPHAN A., PIRIYAMASAKUL S., PRUKSAROJANAKUL W., PEWNIM T. Single Cell Gel Electrophoresis of Microcrustaceans Moina macrocopa Exposed to Cadmium. Veridian E-Journal, Science and Technology Silpakorn University, 5 (1), 36, 2018.

32. DOU J., JIN Y., LI Y., WU B., LI M. Potential genotoxicity and risk assessment of a chlorinated flame retardant, Dechlorane Plus. Chemosphere, 135, 462, 2015.

33. RAJAPAKSE K., DROBNE D., KASTELEC D., MARINSEK-LOGAR R. Experimental evidence of falsepositive Comet test results due to $\mathrm{TiO}_{2}$ particle--assay interactions. Nanotoxicology, 7 (5), 1043, 2013.

34. DI DONATO G., DE MATTHAEIS E., RONCI L., SETINI A. Genotoxicity biomarkers in the amphipod Gammarus elvirae exposed in vivo to mercury and lead, and basal levels of DNA damage in two cell types, Chemical Ecology, 32, 843, 2016.

35. PELLEGRI V., GORBI G., BUSCHINI A. DNA damage detection by Comet Assay on Daphnia magna: application in freshwater monitoring. Science of the Total environment, 705, 2019.

36. CUI R., KWAK J.I., AN Y.J. Comparative study of the sensitivity of Daphnia galeata and Daphnia magna to heavy metals. Ecotoxicology and Environmental Safety, 162, 63, 2018.

37. WU P., LI C., CHEN J., ZHENG C., HOU X. Determination of cadmium in biological samples: An update from 2006 to 2011. Applied Spectroscopy Reviews, 47, 327, 2012.

38. PARK J.Y., LEE Y.J., KOEDRITH P., SEO Y.R. Protective role of thioredoxin reductase 1 in cadmium-induced DNA damage. Molecular and Cellular Toxicology, 8, 289, 2012.

39. GARCÍA-MEDINA S., GALAR-MARTÍNEZ M., GÓMEZ-OLIVÁN L.M., RUIZ-LARA K., ISLASFLORES H., GASCA-PÉREZ E. Relationship between genotoxicity and oxidative stress induced by mercury on common carp (Cyprinus carpio) tissues. Aquatic Toxicology, 192, 207, 2017.

40. CRESPO-LÓPEZ M.E., MACEDO G.L., ARRIFANO G.P.F., PINHEIRO M. DA C., DO NASCIMENTO J.L.M., HERCULANO A.M. Genotoxicity of mercury: Contributing for the analysis of Amazonian populations. Environment International, 37, 136, 2011.

41. GARCÍA-LESTÓN J., MÉNDEZ J., PÁSARO E., LAFFON B. Genotoxic effects of lead: an updated review. Environment International, 36, 623, 2010. 